\author{
Fabio Pereiraํㅜ, Fabiana Vieira ${ }^{1}$, Luiz de Castro $^{1}$ and Ricardo Michel $^{2}$
}

\title{
THE INFLUENCE OF SAMPLE PREPARATION ON THE STRENGTH RESULTS OF A PAN-BASED CARBON FIBER
}

\author{
${ }^{1}$ Centro Tecnologico do Exercito (CTEx) - Avenida das Americas, 28705, Guaratiba, \\ 23020-470, Rio de J aneiro, Brasil; depine@ centroin.com.br \\ ${ }^{2}$ Instituto de M acromoleculas Prof.Eloisa M ano, Universidade Federal do Rio de Janeiro (IMA/ UFRJ), \\ Centro de Tecnologia, Bloco J., 21945-70, Rio de Janeiro, Brasil
}

Received: March 04, 2010 / Revised: May 04, 2010 / Accepted September 07, 2010

(C) Pereira F., Vieira F., de Castro L., Michel R., 2010

\begin{abstract}
In this work the influence of different configurations in the sample preparation process on commercial polyacrylonitrile-based carbon fibers mechanical tests were studied. Mechanical properties, such as tensile strength, Young's modulus, elongation and Weibull modulus, were evaluated. The results showed that all sample preparation steps may have strong influence on the results.
\end{abstract}

Keywords: polyacrylonitrile, carbon fiber, mechanical properties, material testing.

\section{Introduction}

Since the 90's the use of carbon fibers has been growing rapidly. The performance/price ratio is rising and market conditions increasingly favor lighter and stronger commercial products designs [1].

Carbon fibers combine exceptional mechanical properties and low weight, which makes them ideal composite reinforcements. An important amount of scientific and technological work has been done to improve the mechanical properties of carbon fibers [2] and the fiber strength property is the most influential factor on the strength of the composites [3].

An important issue in the mechanical properties of fibers is their variability. Tensile tests on individual fibers show a wide range of strengths and remarkable sample size dependence analogously to the weakest link [3-4], which means that the critical flaw in the fiber will control its strength [5].

This type of variation is typical of those fibers containing a distribution of flaws along their length. Hence, the probability of a flaw on a given length to occur in the test section increases with increasing gauge length [4]. As in brittle materials, carbon fibers tensile strength is controlled by structural flaws [6]. The strength of a carbon fiber is limited by defects of varying severity randomly distributed along its length, the most damaging flaws being the least frequent. The average strength of short fibers is thus greater than that of the long ones [7]. Therefore, the fiber strength is not a unique specific value; it varies from one fiber to another and depends on the length over which it is measured. Tensile tests on fibers show that the measured average strength is strongly dependent on the test section gauge length $[4,5,7]$, but, obviously, there is a minimum length which allows to carry out experimental measurements of strength on an individual fiber. Most analyses extrapolate fiber mean strength and strength distribution data obtained at longer lengths [5]. The authors [5] consider that the most appropriate extrapolation to short lengths is performed by means of a linear logarithmic dependence of gauge length with the tensile strength, however, in many cases, extrapolating fiber mean strength and strength distribution data obtained at long gauge lengths overestimates the fiber strength at short gauge lengths [8] and has to be examined extremely carefully [5].

It is well known that experimentally measured strengths of brittle solids, such as brittle fibers, are subjected to high variability. The scattering of the values can be described by the Weibull distribution function [35]. In one of his most important works [9], Weibull studied various cases, such as the yield strength of steels and fiber strength of Indian cotton.

The Weibull modulus is not a material constant, but gives a good indication of how homogeneous it is [10].

The strength probability distributions proposed by Weibull for brittle materials have found numerous applications. Weibull distribution is a convenient and natural mean of characterizing the scale effect of strength, i.e., the decrease of the strength with the increase of the specimen size. The two-parameter Weibull distribution is apparently the most widely used distribution function for fiber tensile strength. The fiber fracture probability is given by Eq. (1).

$$
F\left(\sigma_{t}\right)=1-\exp \left(-\frac{l}{l_{0}}\left(\frac{\sigma_{t}}{\beta}\right)^{\alpha}\right)
$$


where $\sigma_{t}$ is the applied tensile stress, $\alpha$ and $\beta$ stand for the shape and scale parameters, respectively, $l$ denotes fiber length, and $l_{0}$ is a normalizing parameter with length dimension [11].

The objective of this work is to achieve a reliable measuring system for individual carbon fiber filaments, by the evaluation of different configurations for tensile tests. A series of mechanical tests were carried out using different gauge lengths, adhesives and support tabs.

\section{Experimental}

\subsection{M aterials}

The fiber used in this work was a commercial polyacrylonitrile (PAN)-based carbon fiber manufactured by Hexcel Carbon Fibers, under the trade name of AS4-GP. The mechanical properties from the producer's data sheet are: tensile strength of $4.3 \mathrm{GPa}$, Young's modulus of $228 \mathrm{GPa}$ and elongation of $1.9 \%$. These values were used as reference values in this work. The average diameter of a single filament is $7 \mu \mathrm{m}$.

To mount the filaments, two kinds of paper were used as support tab: an ordinary and commercial office paper of $75 \mathrm{~g} / \mathrm{cm}^{2}$ and a commercial tissue for lens cleaning, softer than the first one. The individual filaments were fixed on the support tab using three different epoxy resin/ hardener ratios $(30 / 70,50 / 50,70 / 30)$. The adhesive used in this work was a commercial epoxy resin manufactured by NHP Co. Inc., under the trade name of Epoxy 30. The resin curing process was performed at room conditions.

\subsection{Tensile Tests}

The tensile properties of carbon fibers samples were determined using a single filament tensile test, according to ASTM C1557 Standard [12]. The testing machine used during this work was DMA Q800 - TA Instruments and the force rate used was $0.150 \mathrm{~N} / \mathrm{min}$.

The filaments were carefully separated from the carbon fiber tow and then mounted on a support tab as shown in Fig. 1. Extreme care was taken to ensure that the filament was aligned axially with the tensile direction. Prior to the test, the support tab was cut at the sides of the hole, leaving two pieces of paper with the filament endings glued on them (only the filament between the grips).

The tensile strength is obtained from the ratio of the peak force to the cross-sectional area of a plane perpendicular to the fiber axis (Eq. (2)):

$$
\sigma=F / A
$$

where $F$ is a force to failure, $\mathrm{N} ; A$ is fiber cross-sectional area at fracture plane, $\mathrm{m}^{2}$.

The carbon fiber Young's modulus was calculated following the procedure described in the ASTMC1557 Standard.

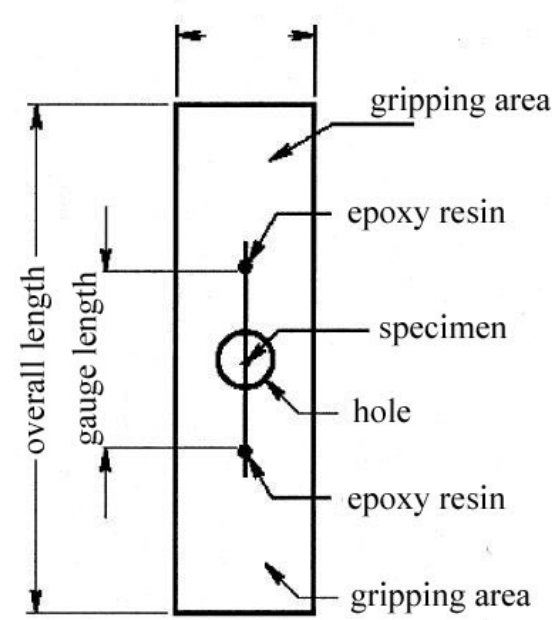

Fig. 1. Support tab for testing fiber filaments according to ASTM C1557 [12]

Tensile tests were performed using different gauge lengths $(6,9$ and $12 \mathrm{~mm})$. For each test, the force versus cross-head displacement curve was constructed. From the curve, the inverse of the slope of the initial linear region was obtained in $\mathrm{m} / \mathrm{N}$. By combining the Eqs. (2), (3), (4) and (5), we obtain Eq. (6), as follows:

$$
\begin{gathered}
\varepsilon=\Delta l / l_{0} \\
\Delta L=\Delta l+C_{s} F \\
\sigma=E \cdot \varepsilon \\
\varepsilon=\frac{\sigma}{E}=\frac{F}{E \cdot A}=\frac{\Delta l}{l_{0}}
\end{gathered}
$$

where $\varepsilon$ is strain, $\Delta l$ is elongation of the gauge length, $\mathrm{m}$; $l_{0}$ is gauge length, $\mathrm{m} ; \Delta L$ is recorded cross-head displacement, $\mathrm{m} ; C_{s}$ is system compliance, $\mathrm{m} / \mathrm{N} ; E$ is Young's modulus.

The combination of Eq. (4) and (6) leads to the Eq. (7):

$$
\frac{\Delta L}{F}=\frac{\Delta l}{F}+C_{S}=\frac{l_{0}}{E \cdot A}+C_{S}
$$

Therefore, a plot of $(\Delta L / F)$ versus $\left(l_{0} / A\right)$ will yield a straight line with the constant slope of $1 / E$, as it is shown in Fig. 2.

The Weibull modulus was calculated for each configuration (different support tabs, resin/hardener ratios and gauge lengths) and was determined by plotting Eq. (8) [9]:

$$
\ln \left(\ln \frac{1}{1-P}\right)=m \cdot \ln \sigma-m \cdot \ln \sigma_{0}
$$

where $P$ is the probability of failure; $m$ is the Weibull shape parameter; $\sigma$ is the tensile strength and $\sigma_{0}$ is the scale parameter. 
The Weibull modulus is obtained by plotting $\ln [\ln (1 /(1-P)]$ versus $\ln \sigma$. The probability of failure for the $i$-th observation is given by $P=i /(N+1)$, where $N$ is the number of individual measurements in a series. The Weibull shape parameter $(m)$ is obtained by linear regression.

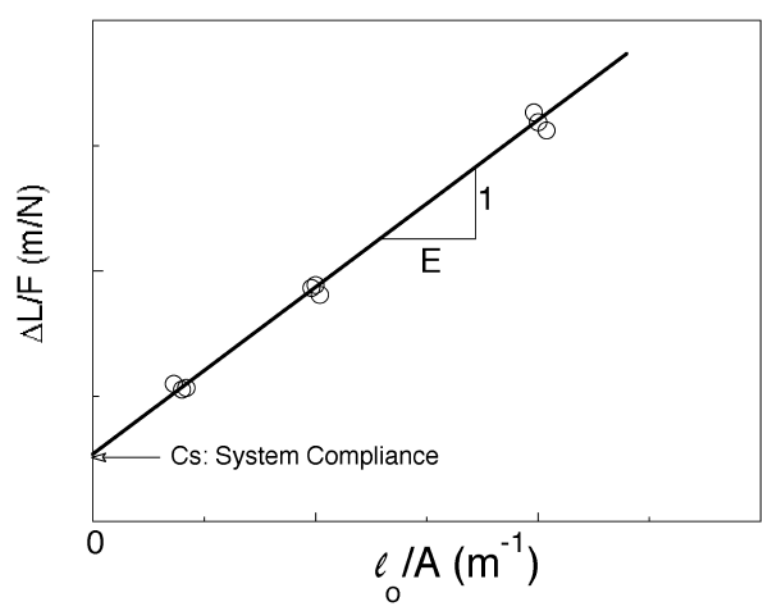

Fig. 2. Method for determining the Young's modulus according to ASTM C1557 [12]

\section{Results and Discussion}

The results obtained for tensile strength, elongation and Young's modulus are summarized in Table 1.

The tensile tests of the carbon fiber showed a brittle behavior which is denoted by a straight line in stress versus strain curve. For the 30/70 resin/hardener ratio, this behavior

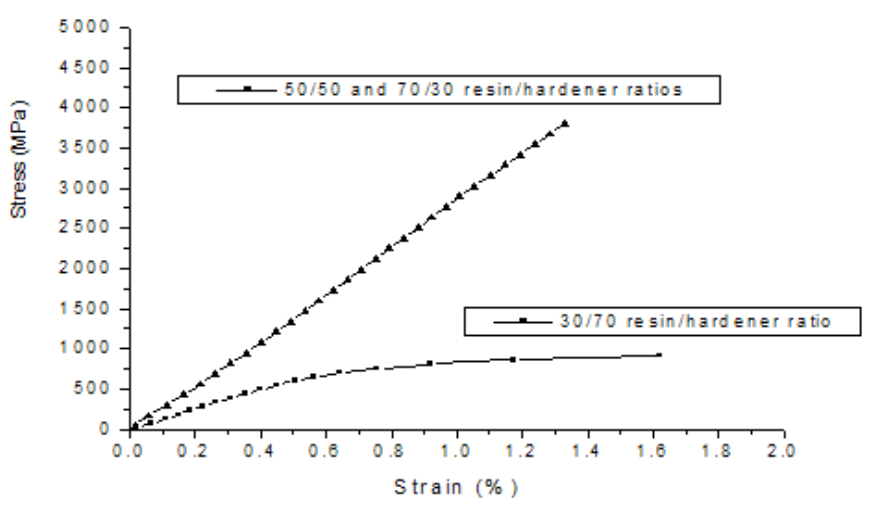

Fig. 3. Representative stress $v s$ strain curves for different resin/hardener ratios

Results obtained for tensile stress, elongation and Young's modulus

\begin{tabular}{|c|c|c|c|c|c|}
\hline \multirow[t]{2}{*}{ Support tab } & \multirow{2}{*}{$\begin{array}{l}\text { Resin/hardener } \\
\text { ratio, } \%\end{array}$} & \multirow{2}{*}{$\begin{array}{c}\text { Gauge } \\
\text { length, } \\
\mathrm{mm}\end{array}$} & $\begin{array}{c}\text { Tensile } \\
\text { stress, GPa }\end{array}$ & Elongation, \% & $\begin{array}{c}\text { Young's } \\
\text { modulus, GPa }\end{array}$ \\
\hline & & & $4.3^{*}$ & $1.9^{*}$ & $228^{*}$ \\
\hline \multirow{9}{*}{ office paper } & \multirow{3}{*}{$30 / 70$} & 6 & $2.1 \pm 0.8$ & $1.0 \pm 0.3$ & \multirow{3}{*}{$340.4 \pm 29.5$} \\
\hline & & 9 & $2.3 \pm 0.6$ & $1.2 \pm 0.3$ & \\
\hline & & 12 & $2.5 \pm 0.5$ & $1.1 \pm 0.2$ & \\
\hline & \multirow{3}{*}{$50 / 50$} & 6 & $3.7 \pm 0.3$ & $1.0 \pm 0.1$ & \multirow{3}{*}{$288.6 \pm 14.2$} \\
\hline & & 9 & $3.7 \pm 0.3$ & $1.2 \pm 0.1$ & \\
\hline & & 12 & $3.7 \pm 0.4$ & $1.3 \pm 0.2$ & \\
\hline & \multirow{3}{*}{$70 / 30$} & 6 & $4.1 \pm 0.5$ & $1.1 \pm 0.2$ & \multirow{3}{*}{$468.2 \pm 54.2$} \\
\hline & & 9 & $3.6 \pm 0.6$ & $1.1 \pm 0.3$ & \\
\hline & & 12 & $3.5 \pm 0.8$ & $1.1 \pm 0.3$ & \\
\hline \multirow{9}{*}{$\begin{array}{l}\text { lens } \\
\text { cleaning } \\
\text { tissue }\end{array}$} & \multirow{3}{*}{$30 / 70$} & 6 & $1.2 \pm 0.4$ & $1.1 \pm 0.6$ & \multirow{3}{*}{$285.9 \pm 48.5$} \\
\hline & & 9 & $1.5 \pm 0.8$ & $1.2 \pm 0.4$ & \\
\hline & & 12 & $1.6 \pm 0.3$ & $1.3 \pm 0.4$ & \\
\hline & \multirow{3}{*}{$50 / 50$} & 6 & $3.9 \pm 0.3$ & $1.1 \pm 0.2$ & \multirow{3}{*}{$366.6 \pm 36.3$} \\
\hline & & 9 & $3.8 \pm 0.3$ & $1.2 \pm 0.1$ & \\
\hline & & 12 & $3.7 \pm 0.4$ & $1.4 \pm 0.2$ & \\
\hline & \multirow{3}{*}{$70 / 30$} & 6 & $3.6 \pm 0.6$ & $1.8 \pm 0.4$ & \multirow{3}{*}{$281.5 \pm 12.1$} \\
\hline & & 9 & $4.0 \pm 0.7$ & $1.2 \pm 0.2$ & \\
\hline & & 12 & $3.8 \pm 0.5$ & $1.3 \pm 0.1$ & \\
\hline
\end{tabular}

* Reference values from the producer's data sheet, as described in section 2.1 
was noticed only at the initial part of the curve, which is followed by a non-linear portion, indicating a plastic deformation. In this case, the values of tensile strength and elongation utilized were those obtained from the linear portion of the stress versus strain curve (Fig. 3).

The non-linear portion in the stress vs strain curve was attributed to an incomplete resin curing process. A period of 48-72 $\mathrm{h}$ was needed to perform the tensile test of the 30/70 resin/hardener ratio samples in both types of support tab, while samples prepared with the other two resin/hardener ratios needed only a period of $12 \mathrm{~h}$ for complete curing.

The values obtained for tensile strength were close to those listed in producer's data sheet which was used as reference value. Although the tensile strength results for $50 / 50$ and 70/30 resin/hardener ratio were very close to each other, the latest, using office paper configuration almost reproduced the producer's data sheet value.

As expected, the short gauge length configurations showed higher values of tensile strength than the long gauge length configurations. Elongation values did not show any dependence on the gauge length value and, in fact, with the exception of the results obtained from 70/30 resin/hardener ratio using lens cleaning tissue, all the others showed similar results. When using the lens cleaning tissue, it was very difficult to mount the single filament on the support tab and this fact could contribute to the increase of the amount of flaws and interfere in its non-alignment on the support tab.

The values of Young's modulus were calculated according to the process described by ASTM C1557 Standard (Figs. 4 and 5). The 30/70 resin/hardener ratio showed poor linear regressions (Figs. 4 and 5), while the other configurations exhibited similar results showing higher values of $R^{2}$.

The values obtained for samples elongation were lower while the values obtained for the tensile strength were higher, which resulted in higher values for the Young's modulus than the one presented at the producer's data sheet used as a reference.

The 30/70 resin/hardener configurations showed higher deviation for Young's modulus values while the 70/ $30 \mathrm{resin} / \mathrm{hardener}$ ratio, using the lens cleaning tissue configuration, exhibited values closer to the reference value.

The Weibull Modulus for each configuration tested was calculated according to Eq. (8). The results obtained are summarized in Table 2.

The graphical representations of the calculations of the Weibull Modulus by linear regression are illustrated in Figs. 6-11. The 30/70 (Figs. 6 and 9) and 50/50 (Figs. 7 and 10) resin/hardener ratios showed similar results, exhibiting a linear regression not as good as the 70/30 resin/hardener ratio (Figs. 8 and 11). The samples mounted over office paper (Figs. 6, 7 and 8) showed similar results to the samples mounted over lens cleaning tissue (Figs. 9, 10 and 11).
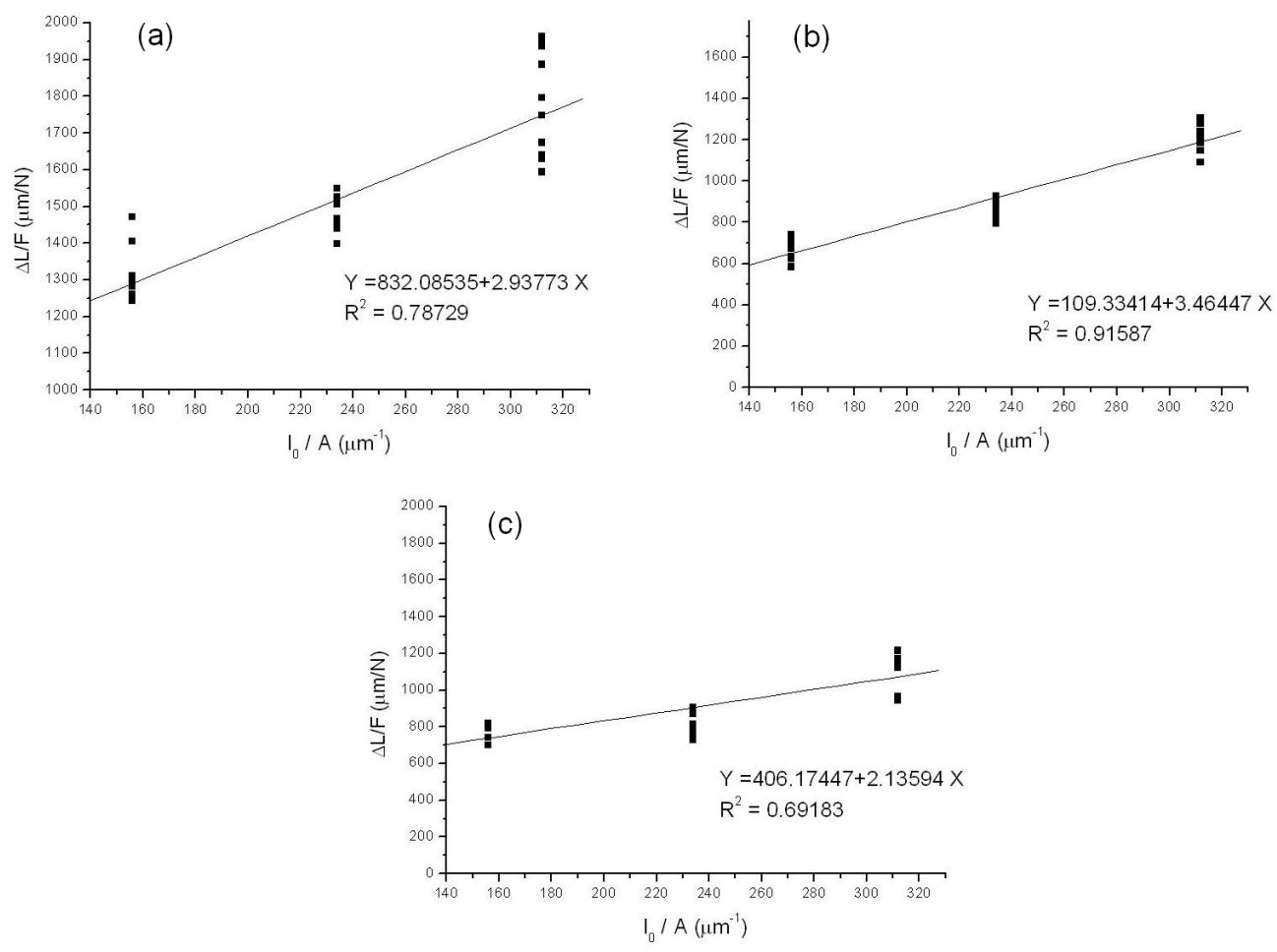

Fig. 4. Young's modulus of samples mounted over office paper with different resin/hardener ratios: $30 / 70$ (a); $50 / 50$ (b) and $70 / 30(c)$ 

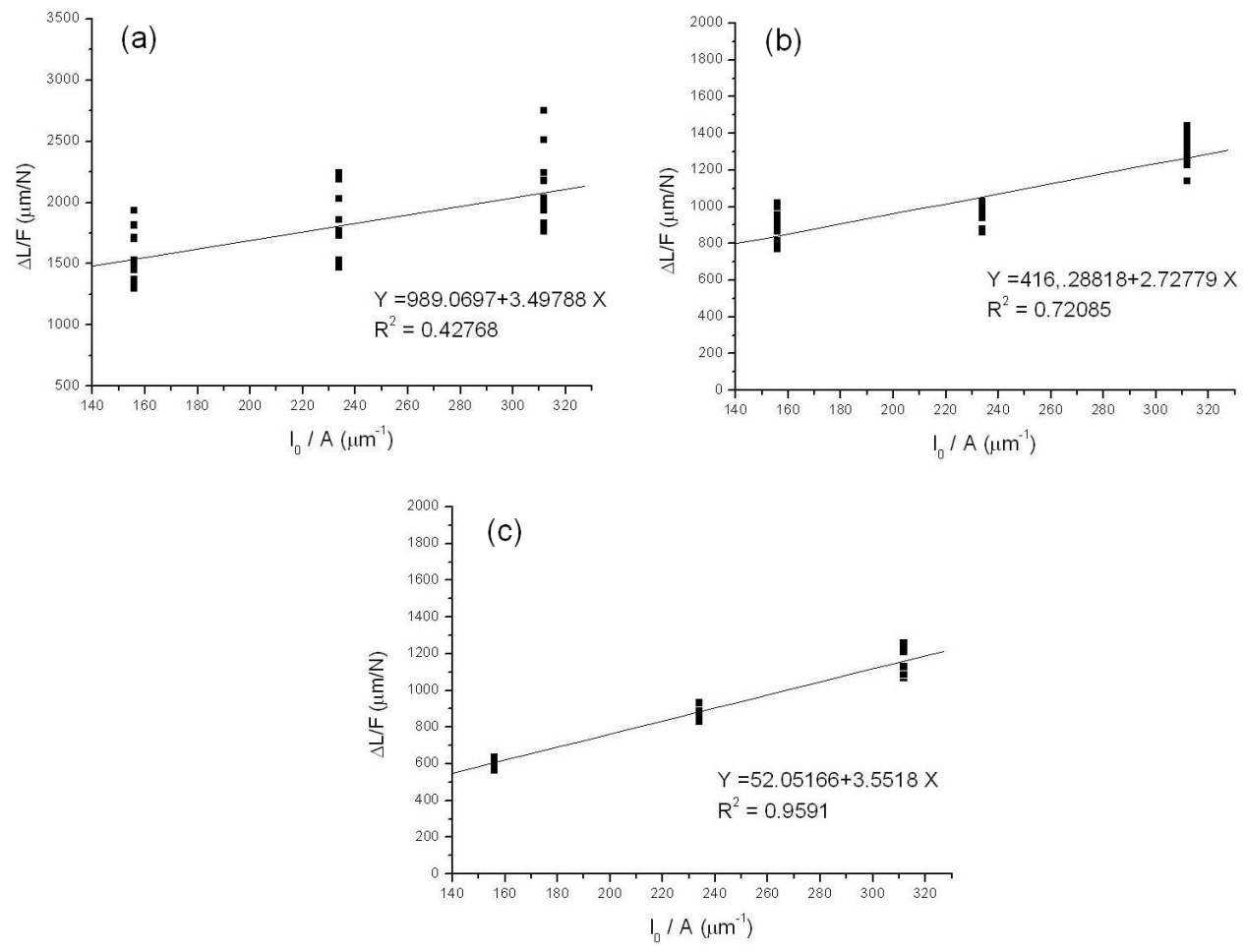

Fig. 5. Young's modulus of samples mounted over lens cleaning tissue with different resin/hardener ratios: 30/70 (a); 50/50 (b) and 70/30 (c)

Table 2

Results obtained for Weibull modulus

\begin{tabular}{|c|c|c|c|}
\hline $\begin{array}{c}\text { Support } \\
\text { tab }\end{array}$ & $\begin{array}{l}\text { Resin/hardene } \\
\text { r ratio, \% }\end{array}$ & $\begin{array}{c}\text { Gauge } \\
\text { length, } \\
\mathrm{mm}\end{array}$ & $\begin{array}{l}\text { Weibull } \\
\text { modulus }\end{array}$ \\
\hline \multirow{9}{*}{$\begin{array}{l}\text { office } \\
\text { paper }\end{array}$} & \multirow{3}{*}{$30 / 70$} & 6 & 2.48 \\
\hline & & 9 & 4.10 \\
\hline & & 12 & 5.48 \\
\hline & \multirow{3}{*}{$50 / 50$} & 6 & 12.44 \\
\hline & & 9 & 11.32 \\
\hline & & 12 & 11.27 \\
\hline & \multirow{3}{*}{$70 / 30$} & 6 & 8.05 \\
\hline & & 9 & 5.38 \\
\hline & & 12 & 4.15 \\
\hline \multirow{9}{*}{$\begin{array}{l}\text { lens } \\
\text { cleaning } \\
\text { tissue }\end{array}$} & \multirow{3}{*}{$30 / 70$} & 6 & 2.10 \\
\hline & & 9 & 1.77 \\
\hline & & 12 & 6.83 \\
\hline & \multirow{3}{*}{$50 / 50$} & 6 & 18.61 \\
\hline & & 9 & 11.52 \\
\hline & & 12 & 8.79 \\
\hline & \multirow{3}{*}{$70 / 30$} & 6 & 4.46 \\
\hline & & 9 & 5.39 \\
\hline & & 12 & 7.51 \\
\hline
\end{tabular}

The Weibull shape parameter " $m$ " indicates the degree of scattering on the strength being a smaller shape parameter an indication of a larger scattering. In this way, it can be regarded as a flaw frequency distribution factor [9]. High values of " $m$ " indicate that the flaws are evenly distributed throughout the material, regardless of whether they are plentiful or not, and hence strength is nearly independent of the length. Low values of " $m$ " indicate that flaws are fewer and less evenly distributed, causing greater scatter in strength [10]. The Weibull shape parameter has also the physical meaning as the factor of size effect on the strength [3]. T. Tagawa [3] confirmed that the tensile strength in carbon fibers almost obeys the single modal Weibull distribution. This suggests that the fracture of a carbon fiber may be controlled by a single mechanism.

With regard to the fracture mechanisms of the carbon fibers, it was proposed that the misorientation of the graphite crystal layers controls the fracture. Weibull shape parameters in axial direction showed almost constant value of four, irrespective of the carbon precursor and the strength level [3].

The Weibull theory also states that for a material with homogeneous quality having a nearly unimodal distribution of flaw size, the value of the Weibull shape parameter should be the same at all sample lengths and the mean value of strength at the different lengths should increase with the decrease in the length [10]. 

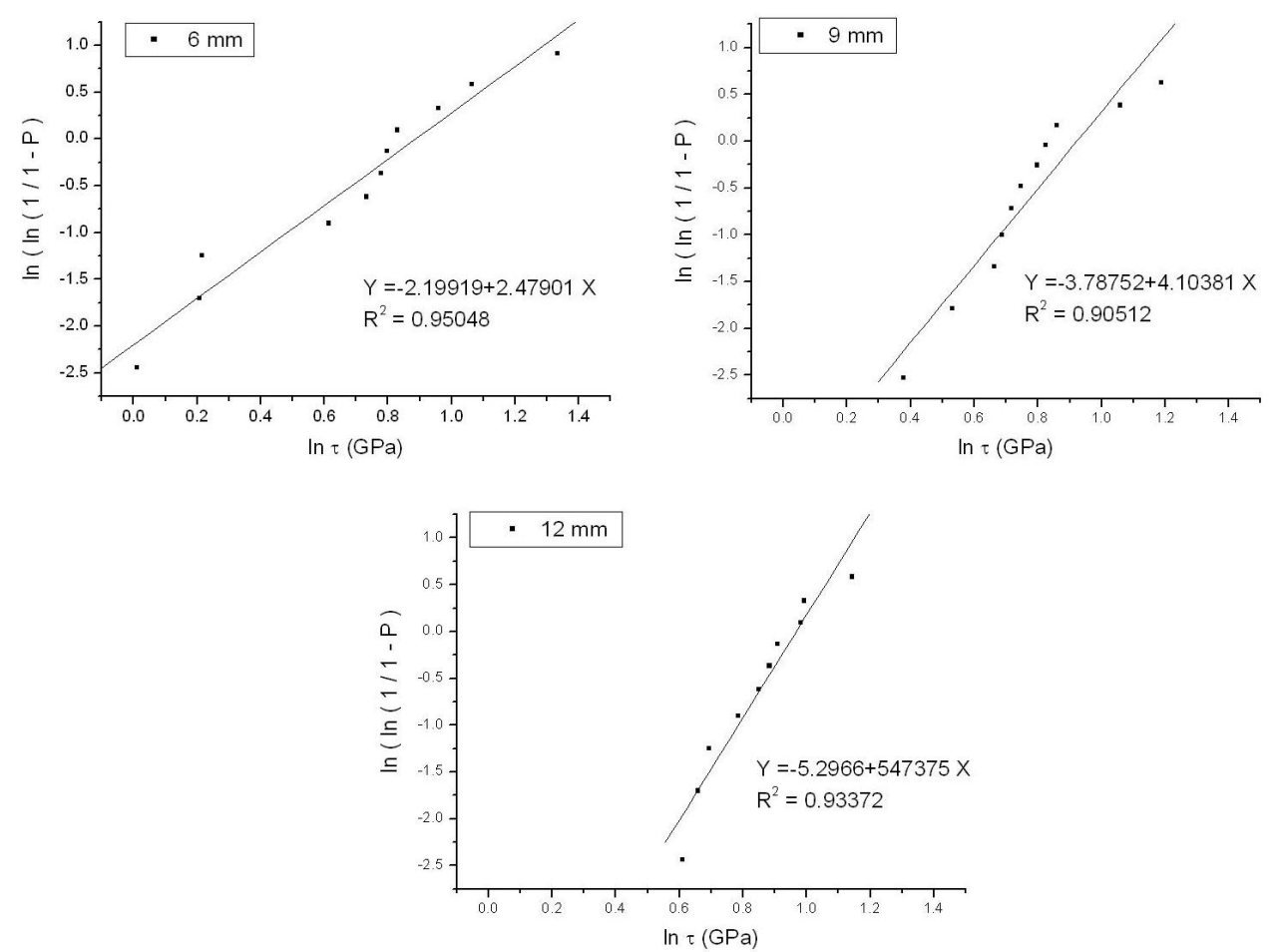

Fig. 6. Weibull plots for tensile strength of $30 / 70$ resin/hardener ratio $-6 \mathrm{~mm}, 9 \mathrm{~mm}$ and $12 \mathrm{~mm}$ samples mounted over office paper
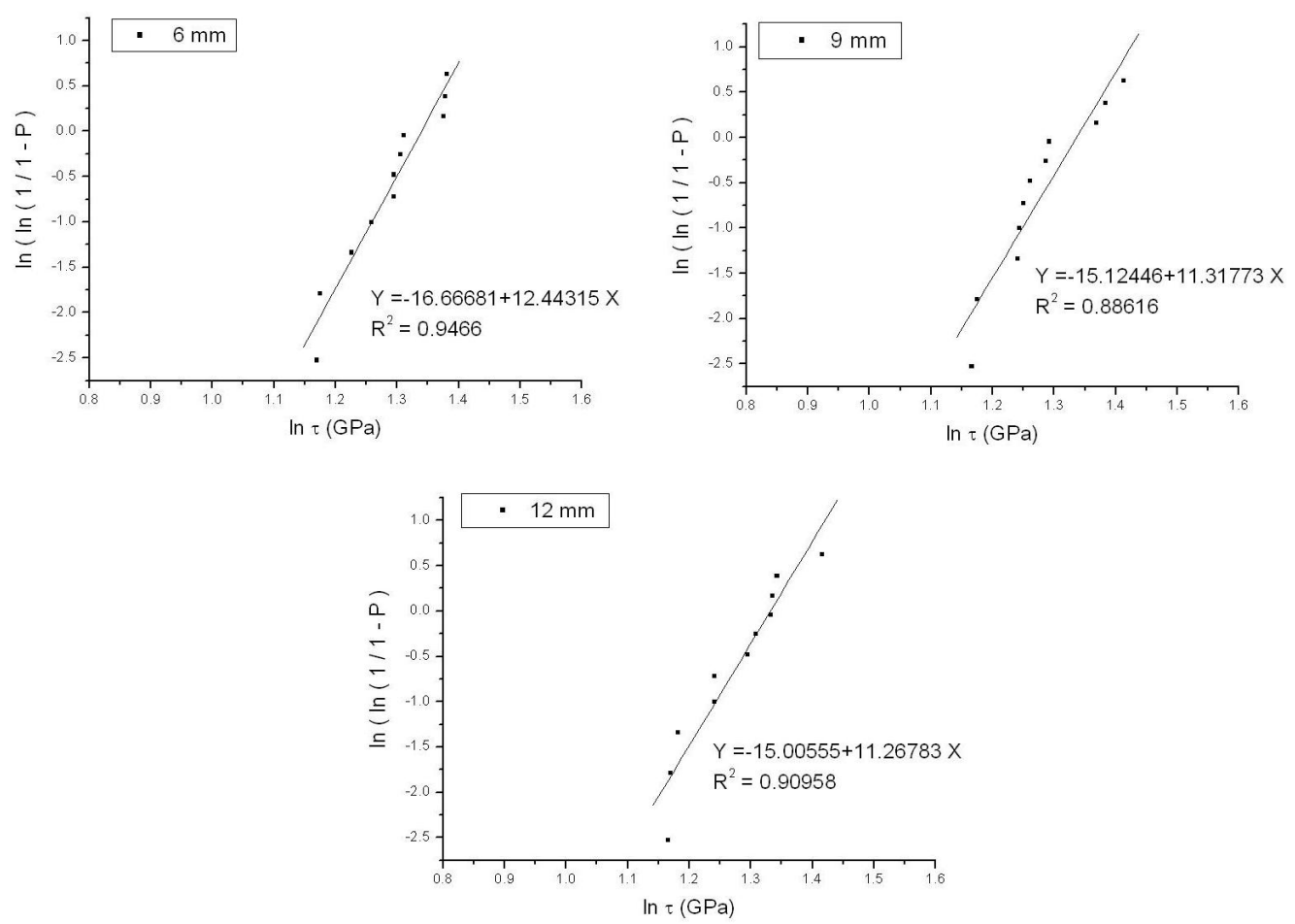

Fig. 7. Weibull plots for tensile strength of 50/50 resin/hardener ratio $-6 \mathrm{~mm}, 9 \mathrm{~mm}$ and $12 \mathrm{~mm}$ samples mounted over office paper 

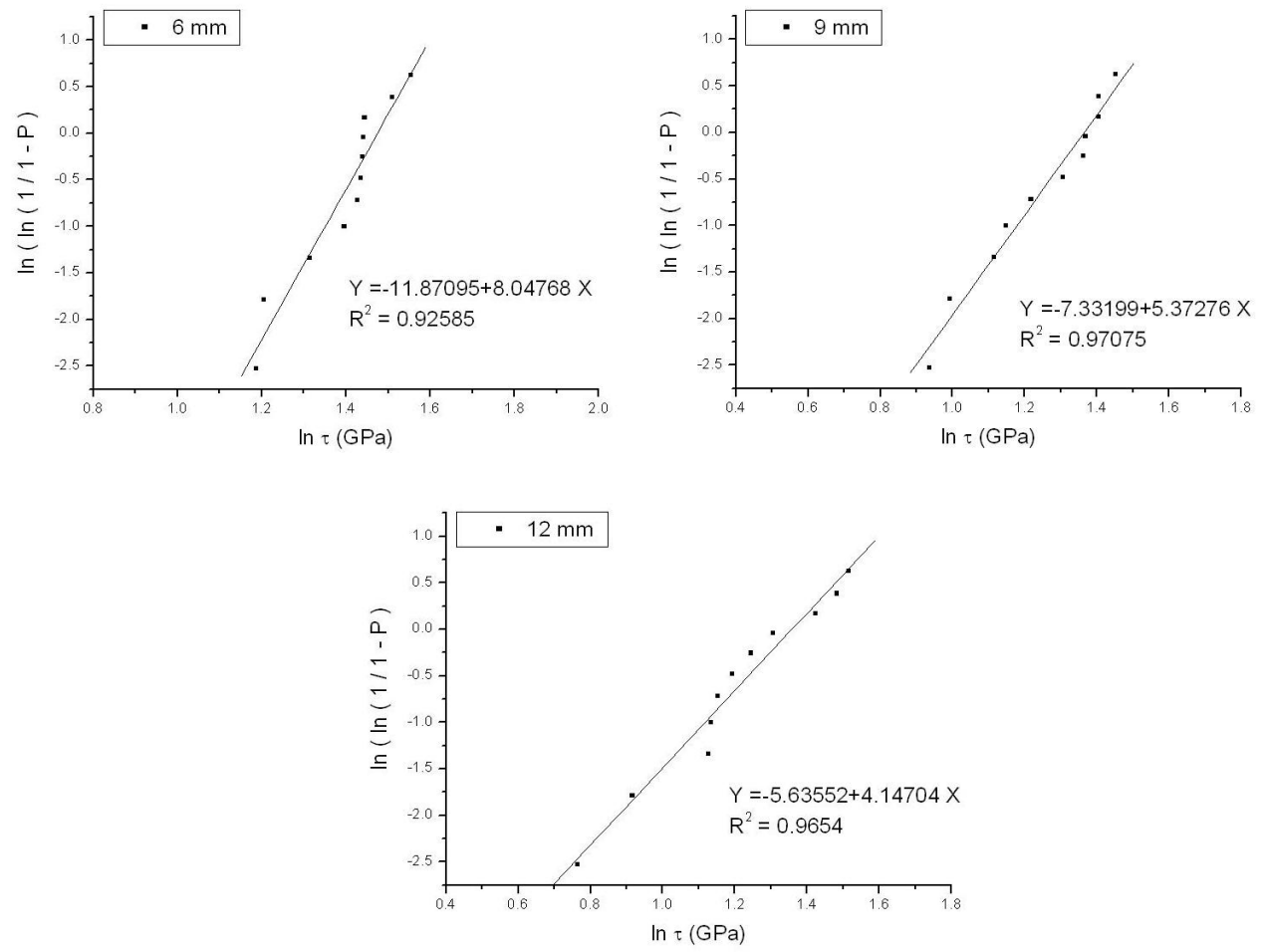

Fig. 8. Weibull plots for tensile strength of $70 / 30$ resin/hardener ratio $-6 \mathrm{~mm}, 9 \mathrm{~mm}$ and $12 \mathrm{~mm}$ samples mounted over office paper
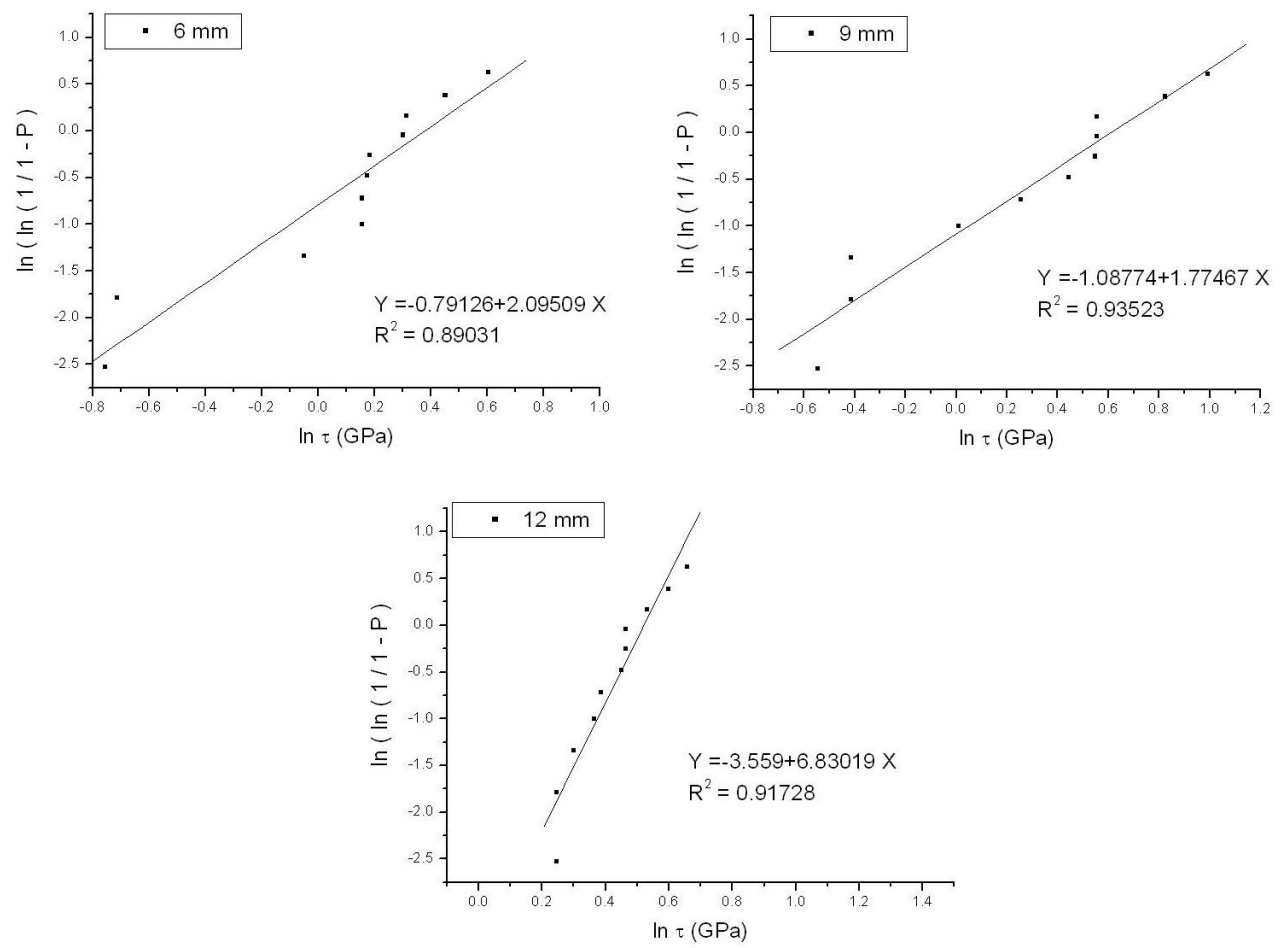

Fig. 9. Weibull plots for tensile strength of 30/70 resin/hardener ratio $-6 \mathrm{~mm}, 9 \mathrm{~mm}$ and $12 \mathrm{~mm}$ samples mounted over lens cleaning tissue 

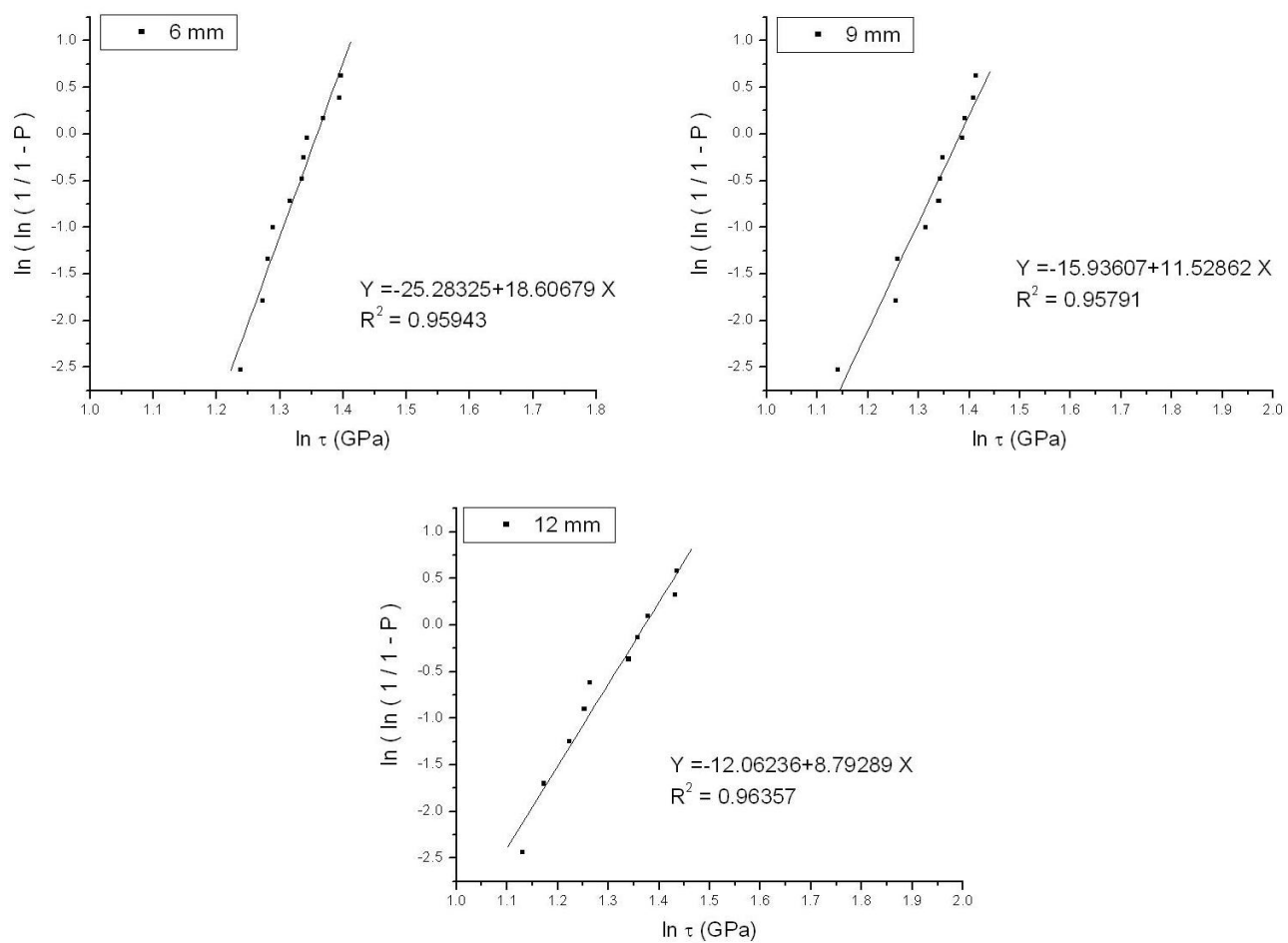

Fig. 10. Weibull plots for tensile strength of 50/50 resin/hardener ratio $-6 \mathrm{~mm}, 9 \mathrm{~mm}$ and $12 \mathrm{~mm}$ samples mounted over lens cleaning tissue
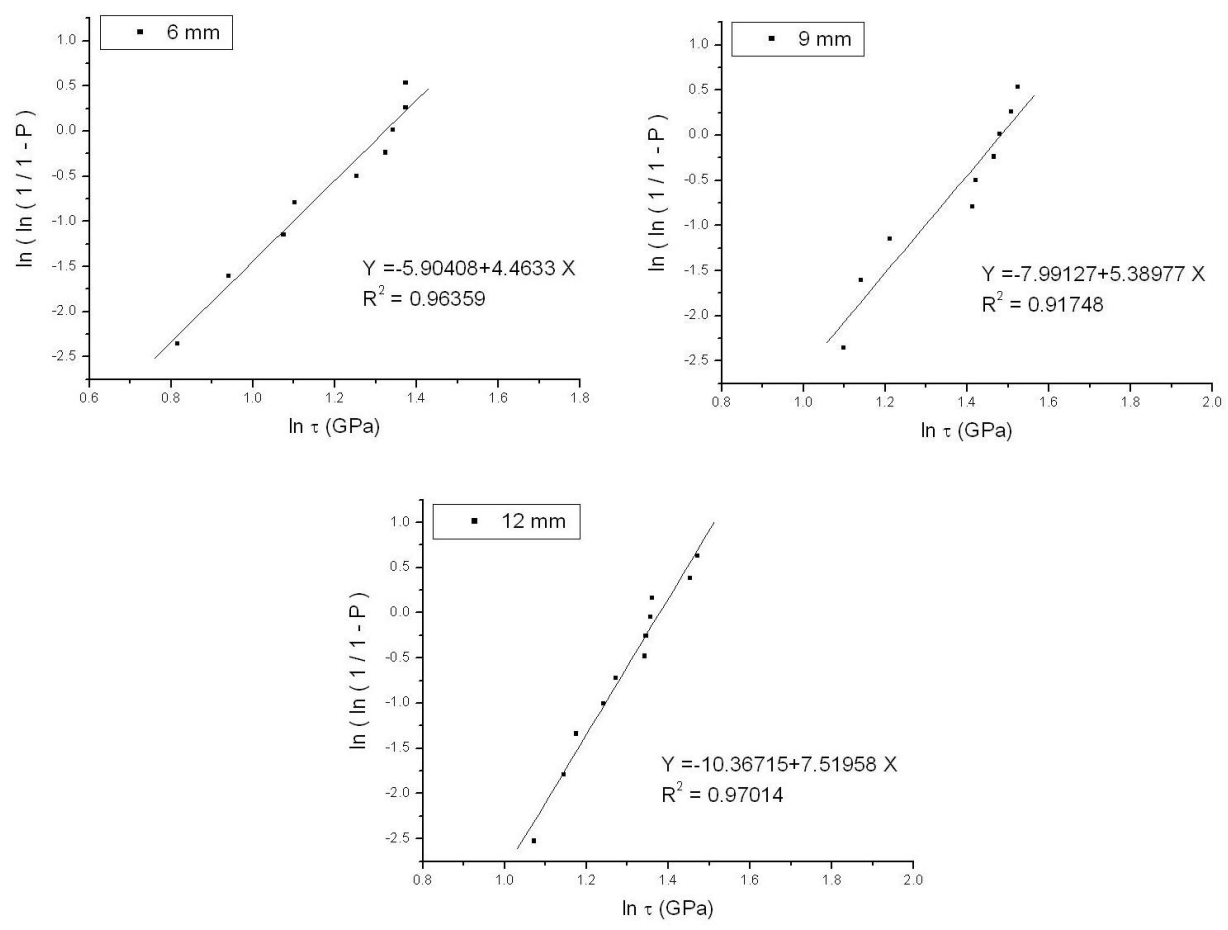

Fig. 11. Weibull plots for tensile strength of 70/30 resin/hardener ratio $-6 \mathrm{~mm}, 9 \mathrm{~mm}$ and $12 \mathrm{~mm}$ samples mounted over lens cleaning tissue 
In this work the short gauge length configurations showed higher values of Weibull modulus than the long gauge length configurations and the higher values of Weibull modulus were obtained using 50/50 resin/hardener ratio with the lens cleaning tissue $-6 \mathrm{~mm}$ configuration. The smaller values of Weibull modulus were obtained using $30 / 70 \mathrm{resin} / \mathrm{hardener}$ ratio with the lens cleaning tissue $6 \mathrm{~mm}$ configuration.

The 50/50 resin/hardener ratio showed the narrower range of values, considering the three gauge lengths evaluated.

\section{Conclusions}

A few sets of configurations were examined in this work to measure carbon fiber strength properties and their importance was verified by the obtained results, showing that there is no sense in presenting just numbers without describing in detail the test condition.

The 30/70 resin/hardener ratio showed much lower values of tensile strength and a broad range of values. This fact is attributed to an incomplete resin curing process. Young's modulus for 30/70 resin/hardener ratio showed higher standard deviation caused by the larger range of tensile strength values. However, both 50/50 and 70/30 resin/hardener ratios showed equally higher results for the tensile strength and similar elongation values. For 50/50 resin/hardener ratio, tensile strength and elongation presented similar values for both office paper and lens cleaning tissue.

Both office paper and lens cleaning tissue showed higher levels of tensile strength for 70/30 resin/hardener ratio. The elongation results, using office paper, were within a short range for all configurations. The measured Young's modulus was higher than the reference value of $228 \mathrm{GPa}$ for the reasons already mentioned.

The lens cleaning tissue configuration combined with 70/30 resin/ hardener ratio exhibited the closest Young's modulus value to the reference $(280 \mathrm{GPa})$. As expected, high values of tensile stress were obtained for shorter gauge lengths. This is credited to an increased number of flaws when higher gauge lengths were used.

Because of the scattering of the tensile strength values, a statistical procedure employing the Weibull concept was used. The values of Weibull modulus varied from 2.48 to 18.61 . For most of the configurations, high values of Weibull Modulus were obtained for shorter gauge lengths. Higher values of Weibull modulus and narrower range of values were established for 50/50 resin/hardener ratios, indicating homogeneous quality and unimodal distribution of flaws. In the case of 30/70 resin/hardener ratio, the incomplete resin curing process caused a broad range of tensile strength values, leading to smaller values of Weibull modulus. The resin/hardener ratio showed influence on the Weibull modulus, while the type of support tab showed almost no influence.

\section{Acknowledgements}

The authors thank Petrobras for the financial support and Centro Tecnologico do Exercito (CTEx) for laboratory facilities.

\section{References}

[1] Walsh P.: Carbon Fibers. ASM Handbook, 2001, 21, 35.

[2] Montes-Moran M., Gauthier W., Martinez-Alonso A. and Tascon J.: Carbon, 2004, 42, 127.

[3] Tagawa T. and Miyata T.: Mat. Sci. Eng., 1997, A238, 336.

[4] Hull D.: An Introduction to Composite Materials. Cambridge University Press, New York 1993.

[5] Asloun E., Donnet J., Guilpain G. et al.: J. Mat. Sci., 1989, 24, 3504.

[6] Johnson D.: Chem. \& Phys. Carbon, 1987, 20, 1.

[7] Hughes J., Morley H. and Jackson E.: J. Phys. D, 1980, 13, 921.

[8] Kruinska I., Zurek W. and Egbers G.: Compos. Sci. Techn., 1995, 54, 169.

[9] Weibull W.: J. Appl. Mechanics, 1951, 18, 293.

[10] Pardini L. and Manhanib L.: Mat. Res., 2002, 5, 411.

[11] Paramonov Y. and Andersons J.: Composites A, 2007, 38, 1227.

[12] ASTM C 1557. Standard Test Method for Tensile Strength and Young's Modulus of Fibers, 2003.

\section{ВПЛИВ СПОСОБУ ПРИГОТУВАННЯ ЗРАЗКІВ НАМЩНІСТЬ ВУГЛЕЦЕВОГОВОЛОКНА НАОСНОВІПАН}

Анотація. Вивчено вплив різних конфігурацій зразків у прочесі їх приготування на механічні властивості вуглецевих волокон на основі поліакрилонітрилу (ПАН). Досліджено такі механічні властивості, як міцність на розривання, модуль Юнга, подовження та модуль Вейбулла. Показано, що всі стадії підготовки зразка мають значний вплив на механічні властивості виробу.

Ключові слова: поліакрилонітрил, вуглечеве волокно, механічні властивості, тестування матеріалу. 